\title{
THE EFFECT OF A NEWLY DEVELOPED HARDENING ACCELERATOR ON THE PROPERTIES OF PORTLAND BLAST- FURNACE SLAG CEMENT
}

\author{
Qijun YU ${ }^{1}$, Wensheng ZHANG $^{2}$, Shuichi SUGITA ${ }^{3}$, Yonghui JIANG $^{4}$ and \\ Xiuji FENG ${ }^{5}$
}

\begin{abstract}
${ }^{1}$ Member of JSCE, Dr. of Eng., Associate Professor, Wuhan University of Technology (Wuhan 430070, P.R. China), now who is a visting scholar in the Dept. of Civil Eng., Hachinohe Institute of Technology (88-1, Ohbiraki, Myo, Hachinohe 031, Japan)

${ }^{2} \mathrm{Ph}$. D graduate student, Institute of Materials, Wuhan University of Technology

(Wuhan 430070, P.R. China)

${ }^{3}$ Member of JSCE, Dr. of Eng., Professor, Dept. of Civil Eng., Hachinohe Institute of Technology (88-1, Ohbiraki, Myo, Hachinohe 031, Japan)

${ }^{4}$ Associate Professor, Institute of Materials, Wuhan University of Technology (Wuhan 430070, P.R. China)

${ }^{5}$ Dr. of Eng., Professor, Institute of Materials, Wuhan University of Technology
\end{abstract}

(Wuhan 430070, P.R. China)

\begin{abstract}
By combining some organic compounds with the ground clinker calcined at $1200-1350^{\circ} \mathrm{C}$ with a composition varied in $\mathrm{CaO}-\mathrm{Al}_{2} \mathrm{O}_{3}-\mathrm{SiO}_{2}-\mathrm{CaF}_{2}-\mathrm{BaSO}_{4}$ system, a new type of low alkali cement hardeningaccelerator has been developed. Experiments show that this accelerator can accelerate the set and significantly enhance both early and late strength of portland blast-furnace slag cement (PBSC), especially the early strength of the cement. The promotion of cement hydration, the early formation of more ettringite $(\mathrm{AFt})$, the good bind among hydrates and the formation of a compact texture in the hydrate are the main reasons for the strength increment.
\end{abstract}

Key Words: hardening-accelerator, cement, set, strength, hydration, AFt, microstructure, porosity

\section{INTRODUCTION}

Nowdays admixture is called as the fifth constituent of concrete ${ }^{1)}$. Although there are numerous kinds of hardening-accelerating agent, chloride or alkali is always an essential constituent as their chemical composition is considered. By using them although the early strength of concrete can be improved generaly its late strength is decreased and durability is worsened. In addition, the alkali contained in the agent whether $\mathrm{K}_{2} \mathrm{O}$ or $\mathrm{Na}_{2} \mathrm{O}$ may cause alkali-aggregate reaction in hardened concrete. As now the importance of late strength particularly the long term durability of concret has been highly recognized and much attention is being paid to them so it seems to be urgent and necessary to develop and use alkali-free hardening-accelerators instead of the traditional alkali-contained ones.

X.J. Feng et al. ${ }^{2)}$ invented a method for producing barium contained sulphoaluminate cement, which is mainly composed of $3 \mathrm{CaO} \cdot 3 \mathrm{Al}_{2} \mathrm{O}_{3} \cdot \mathrm{BaSO}_{4}, \beta-\mathrm{C}_{2} \mathrm{~S}$ and $\mathrm{C}_{4} \mathrm{AF}$ and has the peculiarities of rapid hardening and high late strength. Q.J. Yu et $\mathrm{al}^{3{ }^{3}}$ investigated the effect of $11 \mathrm{CaO} \cdot 7 \mathrm{Al}_{2} \mathrm{O}_{3} \cdot \mathrm{CaF}_{2}$ $\left(\mathrm{C}_{11} \mathrm{~A}_{7} \cdot \mathrm{CaF}_{2}\right)$ and $3 \mathrm{CaO} \cdot 3 \mathrm{Al}_{2} \mathrm{O}_{3} \cdot \mathrm{CaSO}_{4}\left(\mathrm{C}_{4} \mathrm{~A}_{3} \overline{\mathrm{S}}\right)$ on the properties of portland fly-ash cement and found that the compressive strength of the cement at $28 \mathrm{~d}$ could be raised by about $10 \mathrm{MPa}$ when a proper amount of $\mathrm{C}_{11} \mathrm{~A}_{7} \cdot \mathrm{CaF}_{2}$ or $\mathrm{C}_{4} \mathrm{~A}_{3} \overline{\mathrm{S}}$ was added to the cement. Based on above researches we calcined a series of clinker which mainly contained $\mathrm{CaO}$, $\mathrm{Al}_{2} \mathrm{O}_{3}, \mathrm{SiO}_{2}, \mathrm{CaF}_{2}$ and $\mathrm{BaSO}_{4}$ but had different amount of $3 \mathrm{CaO} \cdot 3 \mathrm{Al}_{2} \mathrm{O}_{3} \cdot \mathrm{BaSO}_{4}\left(3 \mathrm{CA} \cdot \mathrm{BaSO}_{4}\right.$ for short in the followings), $\beta-\mathrm{C}_{2} \mathrm{~S}, \quad \mathrm{C}_{12} \mathrm{~A}_{7}$ and $\mathrm{C}_{11} \mathrm{~A}_{7} \cdot \mathrm{CaF}_{2}$ in mineral composition. It was found that the clinkers could really improve the strength of PBSC but the strengthening effect were varied with their mineral components. Furthermore by optimum composition design and compositing the clinker, which had an appropriate composition, with some 
Table 1 Chemical compositions of raw materials (\%)

\begin{tabular}{|l|c|c|c|c|c|c|c|c|c|c|}
\hline Sample & I.L. & $\mathrm{SiO}_{2}$ & $\mathrm{Al}_{2} \mathrm{O}_{3}$ & $\mathrm{CaO}$ & $\mathrm{Fe}_{2} \mathrm{O}_{3}$ & $\mathrm{MgO}$ & $\mathrm{BaO}$ & $\mathrm{SO}_{3}$ & $\mathrm{CaF}_{2}$ & $\Sigma$ \\
\hline Limestone & 42.60 & 0.30 & 0.48 & 55.43 & 0.03 & 0.68 & & & & 99.52 \\
\hline Bauxite & 13.40 & 4.61 & 72.86 & 0.78 & 1.48 & 0.88 & & & & 94.04 \\
\hline Barite & 0.21 & & & 0.43 & & & 59.17 & 29.77 & 6.62 & 96.72 \\
\hline
\end{tabular}

Table 2 Mineral contents of clinker A, B and C (\%)

\begin{tabular}{|l|c|c|c|c|c|}
\hline $\begin{array}{l}\text { Clin- } \\
\text { ker }\end{array}$ & $\begin{array}{l}3 \mathrm{CA} \cdot \\
\mathrm{BaSO}_{4}\end{array}$ & $\mathrm{C}_{12} \mathrm{~A}_{7}$ & $\begin{array}{l}\beta- \\
\mathrm{C}_{2} \mathrm{~S}\end{array}$ & $\mathrm{C}_{4} \mathrm{AF}$ & $\begin{array}{l}\mathrm{C}_{11} \mathrm{~A}_{7} \\
\mathrm{CaF}_{2}\end{array}$ \\
\hline $\mathrm{A}$ & 79.5 & 0 & 15.7 & 2.8 & 0 \\
\hline $\mathrm{B}^{*}$ & 55.9 & 0 & 13.3 & 2.3 & 25.3 \\
\hline $\mathrm{C}^{* *}$ & 37.9 & 24.6 & 14.7 & 2.6 & 18.0 \\
\hline
\end{tabular}

kinds of organic compound, a new type of low alkali cement hardening accelerator was developed. Experiments showed with an optimum addition of it to PBSC its early and late strength were increased in a large scale.

In this paper the preparation of this accelerator and its influence on the properties of PBSC are briefly introduced.

\section{EXPERIMENTS AND RESULTS}

\section{(1) Raw materials}

Limestone, bauxite and barite used in the experiment are industrial materials, their chemical compositions are listed in Table 1. The used PBSC was commercial one produced by Yiye Cement Plant, containing $65 \%$ blast-furnace slag, $30 \%$ portland cement clinker and 5\% gypsum.

\section{(2) Clinker sintering and its influence on the properties of PBSC}

By trials and optimum composition design three kinds of clinker (A, B and $\mathrm{C}$ ) which consisted of $\mathrm{CaO} 20-50 \%, \mathrm{Al}_{2} \mathrm{O}_{3} 10-40 \%, \mathrm{SiO}_{2} 5-20 \%, \mathrm{BaO} 10-$ $50 \%, \mathrm{SO}_{3} 4-25 \%$ and slight fluoride were obtained by clinkering the mix of limestone, bauxite and barite at $1200-1350^{\circ} \mathrm{C}$, in which $\mathrm{fCaO}$ was not found by chemical analysis. XRD patterns of the clinkers showed that the expected minerals had been formed and their contents (Table 2), determined by QXRD, were approximately equal to the designed. In order to investigate the effect of the clinkers on the properties of PBSC, ground A, B and C, 5\% by weight, was respectively added to it. The strength specimens of $40 \times 40 \times 160 \mathrm{~mm}$ were made at a water cement ratio of 0.46 and sand cement ratio of 2.5 , then cured at $20 \pm 1^{\circ} \mathrm{C}$ in the air of R.H. $>90 \%$ for $1 \mathrm{~d}$. After demoulding they were cured in water at $20 \pm 1^{\circ} \mathrm{C}$ to different ages. The setting time and strength of the PBSC with or without the addition of different clinkers are shown in Table 3.

\section{(3) Hardening-accelerator preparation and its effect on the properties of PBSC}

Table 3 shows the clinker can increae the early strength of PBSC but its effect on 28d strength improvement is not very evident. By further experiments it was found that the mixture of clinker $C$ and an organic compound $\mathrm{D}_{1}$ (lignin sulfonic calcium) or $\mathrm{D}_{2}$ ( $\beta$-naphthalene sulfonated formaldehyde condensates) or both of them, called $F$ series hardening accelerator (FHA), could significantly improve both early and late strength of PBSC (Table 4). In which the mixture containing clinker $C, D_{1}$ and $D_{2}$ had the best promotion effect on the strength of PBSC. The experimental conditions were as same as before.

\section{(4) Non-evaporable water in the PBSC pastes} with or without clinker $C$ or FHA addition

The content of non-evaporable water in the PBSC pastes at a water cement ratio of 0.30 , with or without clinker $\mathrm{C}$ and FHA addition, was determined by ignition loss method ${ }^{4), 5)}$. The results are shown in Table 5.

\section{(5) SEM analysis of the pastes}

Fig. 1 shows the SEM images of the PBSC pastes hydrated for $3 \mathrm{~d}, 7 \mathrm{~d}$ and $28 \mathrm{~d}$. Although needle-like $\mathrm{AFt}$ had been formed in the paste hydrated for 3d, a porous structure with apparent gaps and large holes could be observed in the paste for 28d (Fig. 1-c).

Fig. 2-a indicates more AFt crystals grow and gather in the hole of $\mathrm{F}_{4}$ paste for $3 \mathrm{~d}$, through their interlacement hydration products and unhydrated cement particles are bound together. Fig. 2-b also shows that plate-like hydration products play a role of bonding and bridging in the paste. From the comparison of Fig. 1-c with Fig. 2-c it can be found that the structure of $F_{4}$ paste is more compact than that of PBSC paste.

\section{(6) Variation of the pore structure of PBSC paste after the addition of FHA}

The pore size distribution, specific pore volume 
Table 3 Influence of clinker A, B and C on the properties of PBSC

\begin{tabular}{|c|cc|ccc|ccc|}
\hline \multirow{2}{*}{ Sample } & \multicolumn{2}{|c|}{ Setting time $(\mathrm{h}: \mathrm{m})$} & \multicolumn{2}{|c|}{ Flexural strength $(\mathrm{MPa})$} & \multicolumn{3}{|c|}{ Compr. strength (MPa) } \\
& Initial & Final & 3d & $7 \mathrm{~d}$ & 28d & 3d & 7d & 28d \\
\hline PBSC & $1: 54$ & $4: 02$ & $3.1 / 100$ & $4.0 / 100$ & $5.9 / 100$ & $13.4 / 100$ & $21.1 / 100$ & $32.3 / 100$ \\
\hline $\mathrm{F}_{1}(\mathrm{PBSC}+5.0 \% \mathrm{~A})$ & $1: 10$ & $1: 57$ & $3.2 / 103$ & $4.4 / 110$ & $5.9 / 98$ & $16.4 / 122$ & $23.2 / 110$ & $32.4 / 100$ \\
\hline $\mathrm{F}_{2}(\mathrm{PBSC}+5.0 \% \mathrm{~B})$ & $1: 30$ & $3: 50$ & $3.3 / 106$ & $4.4 / 110$ & $6.2 / 105$ & $16.0 / 119$ & $22.2 / 105$ & $33.8 / 105$ \\
\hline $\mathrm{F}_{3}(\mathrm{PBSC}+5.0 \% \mathrm{C})$ & $1: 09$ & $3: 35$ & $3.5 / 113$ & $4.7 / 118$ & $6.0 / 102$ & $16.2 / 121$ & $22.0 / 104$ & $35.2 / 109$ \\
\hline
\end{tabular}

Table 4 Effect of F series hardening accelerator on the properties of PBSC

\begin{tabular}{|c|cc|ccc|ccc|}
\hline Sample & \multicolumn{2}{|c|}{ Setting time(h:m) } & \multicolumn{2}{|c|}{ Flexural strength (MPa) } & \multicolumn{2}{|c|}{ Compr. strength (MPa) } \\
& Initial & Final & 3d & 7d & 28d & 3d & 7d & 28d \\
\hline PBSC & $1: 54$ & $4: 02$ & $3.1 / 100$ & $4.0 / 100$ & $5.9 / 100$ & $13.4 / 100$ & $21.1 / 100$ & $32.3 / 100$ \\
\hline$F_{4}\left(\mathrm{PBSC}+4.7 \% \mathrm{C}+0.3 \% \mathrm{D}_{1}\right)$ & $1: 00$ & $2: 43$ & $3.4 / 110$ & $4.4 / 110$ & $5.9 / 100$ & $16.0 / 119$ & $26.0 / 123$ & $38.0 / 118$ \\
\hline $\mathrm{F}_{5}\left(\mathrm{PBSC}+4.7 \% \mathrm{C}+0.2 \% \mathrm{D}_{2}\right)$ & $0: 48$ & $1: 15$ & $4.3 / 139$ & $5.0 / 125$ & $6.6 / 112$ & $22.4 / 167$ & $30.4 / 144$ & $42.2 / 131$ \\
\hline $\begin{array}{c}\mathrm{F}_{6}\left(\mathrm{PBSC}+4.7 \% \mathrm{C}+0.3 \% \mathrm{D}_{1}\right. \\
\left.+0.2 \% \mathrm{D}_{2}\right)\end{array}$ & $0: 57$ & $1: 45$ & $3.6 / 116$ & $4.8 / 120$ & $6.5 / 110$ & $23.4 / 175$ & $31.6 / 150$ & $51.4 / 159$ \\
\hline
\end{tabular}

Table 6 Porosimetry data of the PBSC pastes with or without the addition of FHA

\begin{tabular}{|c|c|c|c|c|c|c|c|c|}
\hline \multirow{2}{*}{ Sample } & \multirow{2}{*}{ Age } & \multicolumn{5}{|c|}{ Pore size distribution (\%) } & \multirow{2}{*}{$\begin{array}{l}\text { Specific } \\
\text { volume } \\
\left(\mathrm{cm}^{3} / \mathrm{g}\right)\end{array}$} & \multirow{2}{*}{$\begin{array}{l}\text { Most pro- } \\
\text { bable pore } \\
\text { radius }(\AA)\end{array}$} \\
\hline & & $<300 \AA$ & $300-10^{3} \AA$ & $10^{3}-5 \times 10^{3} \AA$ & $5 \times 10^{3}-10 \times 10^{3} \AA$ & $>10 \times 10^{3} \AA$ & & \\
\hline PBSC & $3 d$ & 26.82 & 25.03 & 43.39 & 2.90 & 1.86 & 0.19 & 1981.1 \\
\hline $\mathrm{F}_{4}$ & $3 \mathrm{~d}$ & 31.84 & 47.15 & 19.12 & 0.72 & 1.16 & 0.12 & 967.9 \\
\hline PBSC & $7 \mathrm{~d}$ & 48.51 & 38.40 & 8.89 & 1.79 & 2.40 & 0.14 & 967.9 \\
\hline $\mathrm{F}_{4}$ & $7 \mathrm{~d}$ & 68.97 & 25.40 & 2.35 & 0.61 & 2.59 & 0.08 & 250.9 \\
\hline PBSC & $28 \mathrm{~d}$ & 92.39 & 4.04 & 2.45 & 0.40 & 0.48 & 0.11 & 216.0 \\
\hline $\mathrm{F}_{4}$ & $28 \mathrm{~d}$ & 95.93 & 13.61 & 1.34 & 0.55 & 0.76 & 0.06 & 215.9 \\
\hline
\end{tabular}

Table 5 Non-evaporable water in cement pastes (\%)

\begin{tabular}{|c|c|c|c|}
\hline Sample & $3 \mathrm{~d}$ & $7 \mathrm{~d}$ & $28 \mathrm{~d}$ \\
\hline PBSC & 10.66 & 13.03 & 13.96 \\
\hline $\mathrm{F}_{3}$ & 11.37 & 14.91 & 17.42 \\
\hline $\mathrm{F}_{4}$ & 11.50 & 15.60 & 19.19 \\
\hline $\mathrm{F}_{6}$ & 11.85 & 17.30 & 18.72 \\
\hline
\end{tabular}

and most probable pore radius of $\mathrm{PBSC}$ and $\mathrm{F}_{4}$ pastes hydrated for $3 \mathrm{~d}, 7 \mathrm{~d}$ and $28 \mathrm{~d}$ were analyzed by mercury penetration method. Fig. 3 shows the relation between cumulative pore volume and pore radius of the pastes, Table 6 gives the main porosity parameters of the specimens.

\section{ANALYSIS AND DISCUSSION}

(1) Influence of FHA on the properties of PBSC

From Table 4 it can be known when the mixture of $C, D_{1}$ and $D_{2}\left(C+D_{1}+D_{2}\right)$ was added to PBSC with an amount of $5 \%$ by weight, the compressive strength of PBSC at $3 \mathrm{~d}, 7 \mathrm{~d}$ and $28 \mathrm{~d}$ was raised by $75 \%, 50 \%$ and $59 \%$ respectively, simultaneously its flexural strength was increased by more than $10 \%$. Meantime, we also noticed that the setting time of cement was shortened after the addition of FHA, but it is still in accord with the National Standard of China for portland blast-furnace slag cement. The decrease of setting time of the cement is attributed to the addition of clinker $\mathrm{C}$. Table 2 shows there are much $3 \mathrm{CA} \cdot \mathrm{BaSO}_{4}, \mathrm{C}_{11} \mathrm{~A}_{7} \cdot \mathrm{CaF}_{2}$ and $\mathrm{C}_{12} \mathrm{~A}_{7}$ in 


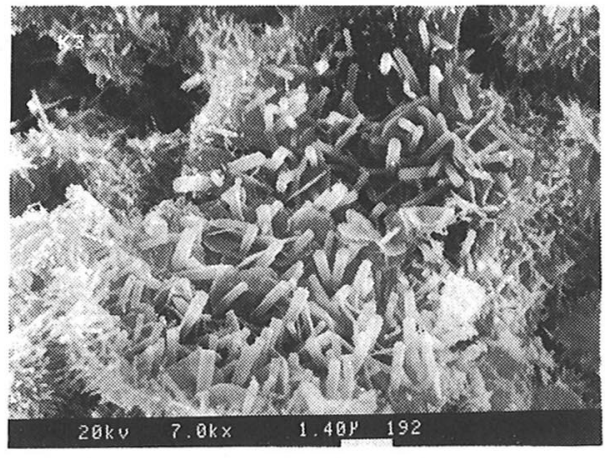

(a) $3 d$

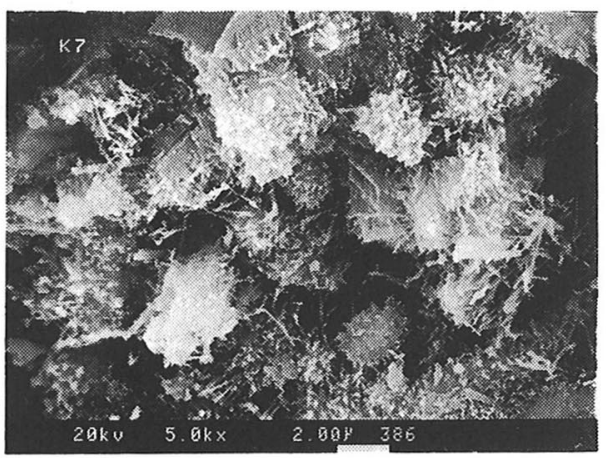

(b) $7 \mathrm{~d}$

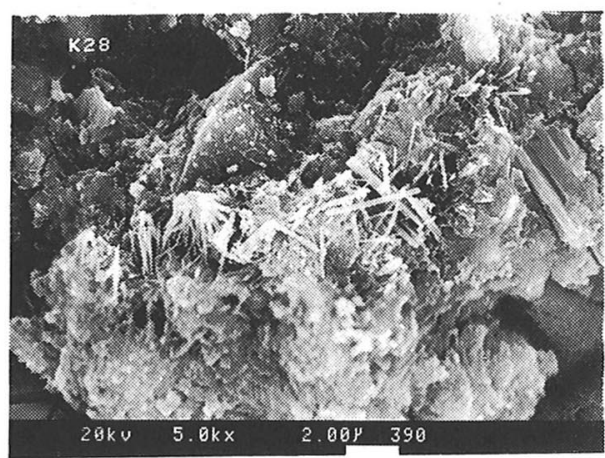

(c) $28 \mathrm{~d}$

Fig. 1 SEM images of hydrated PBSC

clinker $\mathrm{C}$, each of the above compounds has an accelerating effect on the setting and hardening of cement. Yu et al. ${ }^{3)}$ observed the setting of portland fly-ash cement could be considerably accelerated by adding either $\mathrm{C}_{4} \mathrm{~A}_{3} \overline{\mathrm{S}}$ or $\mathrm{C}_{11} \mathrm{~A}_{7} \cdot \mathrm{CaF}_{2}$ (less than $5 \%$ by weight) to it because: 1 ) the hydration of cement was promoted, and 2) compared with control samples more hydrates were formed in the paste

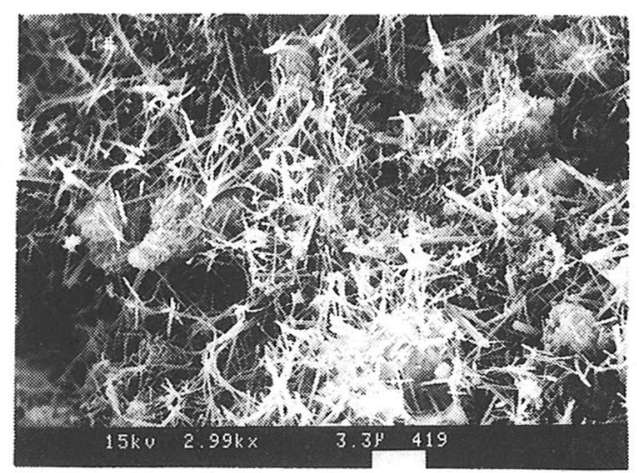

(a) $3 \mathrm{~d}$

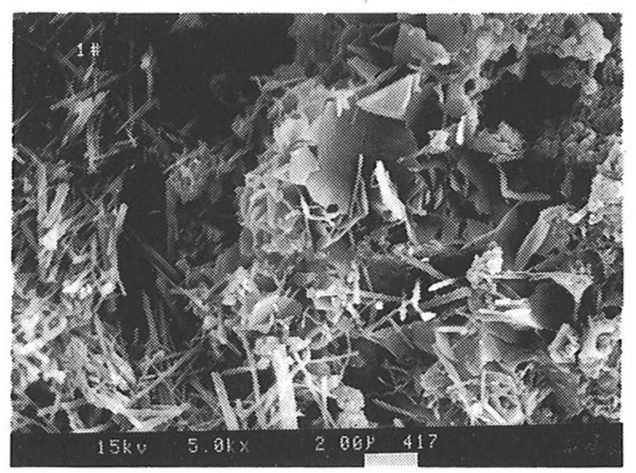

(b) $7 \mathrm{~d}$

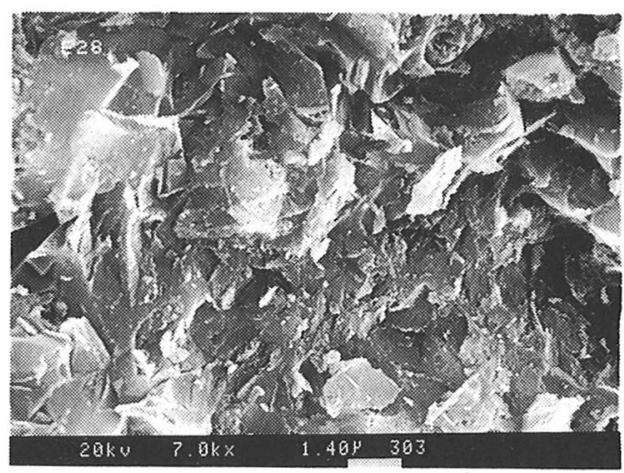

(c) $28 \mathrm{~d}$

Fig. 2 SEM images of hydrated $\mathrm{F}_{4}$

added with $\mathrm{C}_{4} \mathrm{~A}_{3} \overline{\mathrm{S}}$ or $\mathrm{C}_{11} \mathrm{~A}_{7} \cdot \mathrm{CaF}_{2}$.

(2) Effect of FHA on the hydration rate of PBSC

Table 5 shows with the addition of clinker $\mathrm{C}$ to PBSC (sample $\mathrm{F}_{3}$ ) or FHA to PBSC (sample $\mathrm{F}_{4}$ and $F_{6}$ ) the non-evaporable water in pastes is increased, which indicates the hydration degree of PBSC is enhanced by the added clinker $\mathrm{C}$ or FHA. 


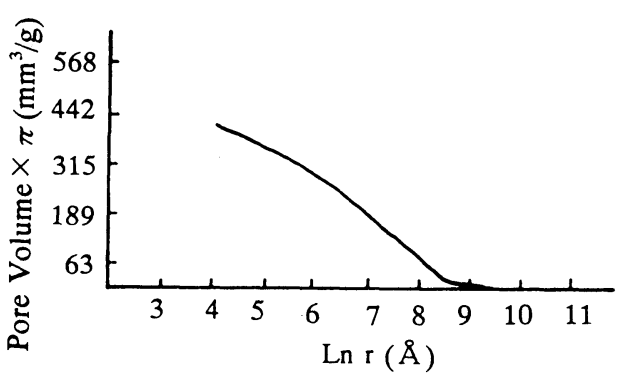

(a) PBSC-3d

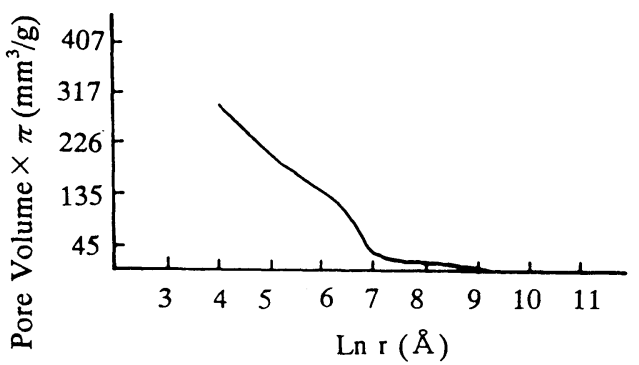

(b) PBSC-7d

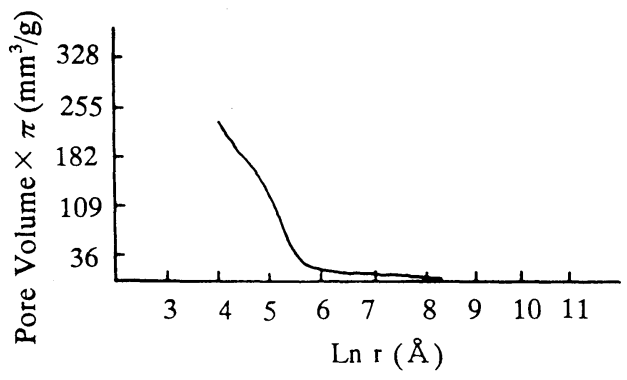

(c) PBSC-28d

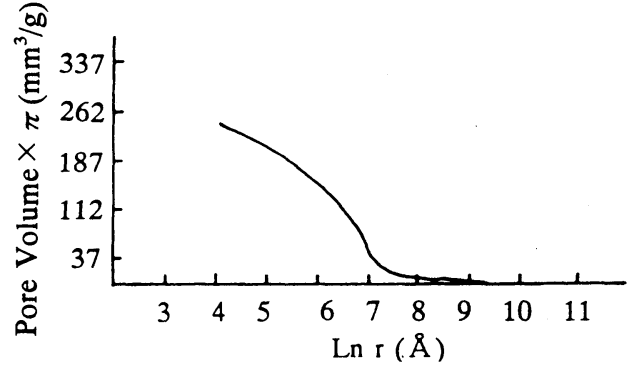

(d) $F_{4}-3 d$

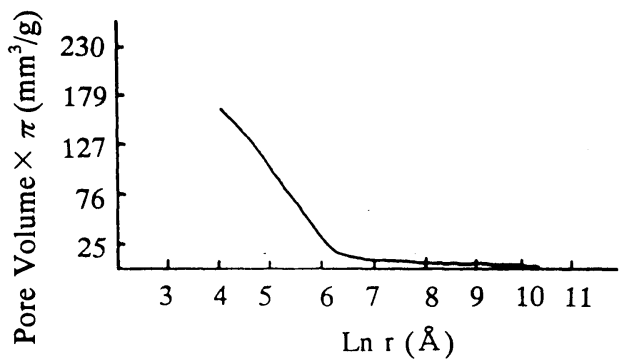

(e) $F_{4}-7 d$

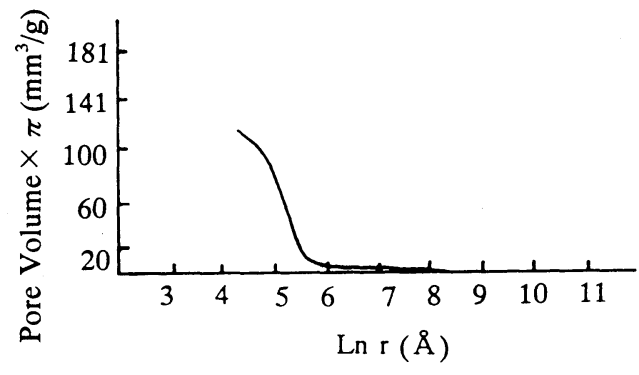

(f) $F_{4}-28 d$

Fig. 3 Relation between cumulative pore volume and pore radius ( $\mathrm{Ln} r$ ) of hydrated PBSC and $\mathrm{F}_{4}$

Furthermore the accelerating effect of the mixture consisted of $C$ and $D_{1}\left(C+D_{1}\right)$ or together with $D_{2}$ $\left(C+D_{1}+D_{2}\right)$ on the hydration of PBSC is more evident compared with that of clinker $\mathrm{C}$. This was confirmed by XRD analysis, at the same hydration age the diffraction intensity of unhydrated clinker minerals in PBSC paste is higher than that in $\mathrm{F}_{3}, \mathrm{~F}_{4}$ and $F_{6}$ pastes, but the intensity of the peak ( $d$ $=9.82 \AA)$ belonging to $\mathrm{AFt}$ and the peak $(\mathrm{d}=4.91 \AA)$ for portlandite are varied in the sequence of $\mathrm{PBSC}<$ $\mathrm{F}_{3}<\mathrm{F}_{4}<\mathrm{F}_{6}$.

\section{(3) Mechanism of strength increment}

Cement strength has a close relation with its hydration degree and the porosity and microstructure of hydrates as well as the kind, shape of hydration products. Based on this research the reasons for the strengthening effect of FHA on the strength of PBSC can be mainly attributed to the followings:
1) FHA accelerates the hydration of PBSC. At a definite age the promotion of hydration, which means the amount of hydration product is increased, necessarily leads to the raise of cement strength.

2) More AFt are formed in the paste, particularly the early formation of AFt due to the rapid hydration of $3 \mathrm{CA} \cdot \mathrm{BaSO}_{4}$ contained in $\mathrm{FHA}$ contributes much to the enhancement of early strength. It was found that in the hydrated barium contained sulphoaluminate cement the hydration products, e.g. AFt and plate-like hydrates, were all doped with barium ions and had a characteristics of forming a wellinterlaced network in the paste, which made hydrates and unhydrated particles closely bond together ${ }^{2), 6)}$, this phenomenon also occurs in the paste with FHA addition. On the other hand AFt fills in the holes in the paste and makes paste structure compact, which also improves the strength of PBSC.

3) The addition of FHA to PBSC makes the pore 
distribution of the paste be beneficial to strength development. Table 6 shows the specific pore volume, the percentage of the pores with radius larger than $1000 \AA$ and the most probable pore radius in hydrated $\mathrm{F}_{4}$ are remarkably reduced compared with those of PBSC paste, but in which the relative content of the pores with radius less than $300 \AA$, i.e. the mesopores, is increased, which means after the addition of FHA to PBSC not only the total porosity and the amount of large pores of the pastes are decreased but also the pores are changed to be mainly distributed in small sizes. Both of them reveal that a compact structure with low porosity has been formed in the hydrates with FHA addition, which also results in the increase of strength. From this result it can be also predicted that the addition of FHA to PBSC is possibly advantageous to the improvement of the resistance of PBSC concrete to penetration.

\section{(4) On the corrosion of steel in the concrete added with FHA}

The industrial utilization of fluor spar and gypsum as composite mineralizer in the production of cement clinker began from 1950 s, then it has been widely spread in some countries, especially in China, for energy-saving consideration. The $\mathrm{CaF}_{2}$ weight percentage of fluorine-contained clinker is about $0.5-1.0 \%$, but up to now it has not been observed that the corrosion of the steel in the concrete made of fluorine-contained cement is considerably accelerated. The amount of $\mathrm{CaF}_{2}$ in clinker $\mathrm{B}$ and $\mathrm{C}$ is $1.40 \%$ and $0.98 \%$, so the corrosion rate of steel may not be increased by adding only about $5 \%$ of them to cement.

\section{CONCLUSIONS}

(1) At $1200-1350^{\circ} \mathrm{C}$ the clinker used as the main constituent of hardening accelerator can be calcined, which is mainly consisted of $3 \mathrm{CaO} \cdot 3 \mathrm{Al}_{2} \mathrm{O}_{3}$. $\mathrm{BaSO}_{4}, \beta-\mathrm{C}_{2} \mathrm{~S}, \mathrm{C}_{12} \mathrm{~A}_{7}$ and $\mathrm{C}_{11} \mathrm{~A}_{7} \cdot \mathrm{CaF}_{2}$. Afte it is composited with some organic compounds, a new type of low alkali cement hardening-accelerator (FHA) is developed, which can significantly increase the early and late strength of PBSC. For instance by adding 5\% of it to PBSC the compressive strength of the cement at $3 \mathrm{~d}$ and $28 \mathrm{~d}$ were respectively increased by $75 \%$ and $59 \%$.

(2) The strength increment of PBSC with FHA addition is attributed to: 1 ) the promotion of cement hydration, 2) the early formation of more AFt, 3) the improvement of the bind among hydrates and unhydrated cement particles, and 4) the decrease of the total porosity and pore size of cement paste.

ACKNOWLEDGMENT: The authors are grateful to the Chenguang Foundation set by Wuhan Science and Technology Committee for its financial support for this project.

\section{REFERENCES}

1) Z.B. YAO: A Practical Handbook on A dmixtures Used in Building Materials, Hehai University Press, Nanjing, pp.1-3, 1993 (in Chinese).

2) X.J. FENG, G.L. LIAO and Z.H. LI: Research on the barium doped sulphoaluminate cement, $J$. of Wuhan University of Technology, Vol.14, No.2, pp.37-42, 1992 (in Chinese).

3) Q. J. YU and D. H. ZHANG: Mechanism of $C_{11} A_{7}$. $\mathrm{CaF}_{2}$ or $\mathrm{C}_{4} \mathrm{~A}_{3} \overline{\mathrm{S}}$ addition on the strength increase of portland fly-ash cement, $J$. of Chinese Ceramics Society, Vol.19, No.6, pp.565-571, 1991 (in Chinese).

4) Czernin, W.: Zementchemie für Bauingenieure, Japanese version, Translated by Yoshio Tokune, Technology Information Press of Japan, pp.44-45, 1969.

5) Taylor, H. F. W.: Cement Chemistry, Academic Press, London, pp.130-131, 206-207.

6) P. YAN: The hydration of $3 \mathrm{CaO} \cdot 3 \mathrm{Al}_{2} \mathrm{O}_{3} \cdot \mathrm{BaSO}_{4}$ in the presence of sulphates, Advances in Cement Research, Vol.18, No.5, pp.65-69, 1993.

(Received July 25, 1996)

\section{新開発硬化促進材の高炉セメントへの効果}

\section{余 其俊 · 張 文生 · 杉田 修一・蒋 永恵 · 馮 修吉}

$\mathrm{CaO}-\mathrm{A}_{2} \mathrm{O}_{3}-\mathrm{S} \mathrm{i} \mathrm{O}_{2}-\mathrm{Ca} \mathrm{F}_{2}-\mathrm{Ba} \mathrm{S} \mathrm{O}$ 組成をさまざまに含む合成物, 1200 〜 $1350^{\circ} \mathrm{C} て ゙$ 焼成された粉砕クリンカーと有機化合物に混ぜることによって, 新しいタイプ の弱アルカリ性セメント硬化促進材が開発された。 この促進材が凝結を促進することができ, また重要なことに高炉セメントの初期及び長期強度, 特に初期強度を高めることを実験で示し た。セメント水和作用の促進，より多くの A F t の早期形成，水和物間のすぐれた結合，そ して水和物の密実構造の形成が, 強度増加の主な理由である. 